\title{
Comparative Analysis of the State of Religious Pluralism between Intertestamental Palestine and Post-Apartheid South Africa
}

\author{
Vusimuzi Goodman Nkuna' \\ 1 South African Theological Seminary, Sandton, South Africa.
}

\begin{abstract}
Religious pluralism has characterized societies since time immemorial and has been one of the sources of conflict in many societies. This article compares how religious pluralism was handled in intertestamental Palestine and the manner it is managed in post-apartheid South Africa. The study used academic literature which applied the Apocrypha to describe the religious context of Palestine between 336 $\mathrm{BC}$ and $63 \mathrm{BC}$. The themes that emerged from this analysis were then used to source academic literature that describes the religious context of South Africa from 1994 to 2021. This process led to the synthesis of the similarities and differences of the two contexts. The findings latently reveal the contribution of the Apocrypha to theological reflection while simultaneously showing that the Roman Empire's violent attempts to undermine religious pluralism in intertestamental Palestine bred counterviolence. The paper further reveals that post-apartheid South Africa's use of legal instruments to promote religious pluralism seems to contribute to the optimization of religious freedom and peaceful co-existence. These findings are likely to contribute to the discourse of religious pluralism, interfaith dialogue, and intercultural communication.
\end{abstract}

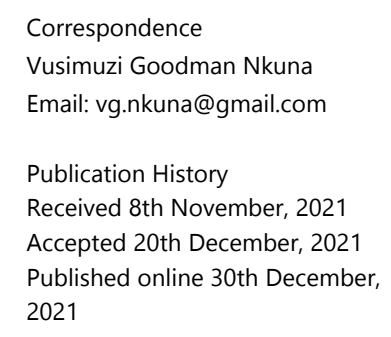

2021

Keywords: Hellenism, Apocrypha, Religious Pluralism, Democracy

\section{INTRODUCTION}

This article presents a comparative analysis of the religious contexts of Palestine from $336 \mathrm{BC}$ to $63 \mathrm{BC}$ and that of post-apartheid South Africa from 1994 to 2021. While the context of Palestine was under imperial rule and the South African context is under a democratic dispensation, both milieus are characterized by political involvement in addressing religious pluralism. The article argues that these two unique political environments directly influence their respective religious contexts. As Palestine was under a violent military rule, coercive tactics were used to suppress Judaism while intentionally promoting Greek pagan religion. In the case of South Africa, democratic instruments such as the country's constitution, bill of rights and related policies are used to enforce religious pluralism.

In presenting the comparative analysis, the paper initially discusses the religious environment of Judaism under Hellenism. It outlines the influence of Hellenism on religion in Palestine, extrapolates how various religious convictions influenced their respective adherents' political ideology and how the Jews used religion as a resource in their daily affairs. Findings under these themes are then contrasted with the religious context of democratic South Africa, namely recognition of religious pluralism, the institutionalization of religious pluralism, perpetual diversity within Christianity, and priestly strife in some populous African 
Independent Churches. The paper also discusses how freedom of religion in post-apartheid South Africa enables some senior politicians to freely exercise their choice to cite the Bible in public speeches without prejudice. ${ }^{1}$

\section{METHODOLOGY}

The study uses an interpretive approach to conduct a thematic analysis of secondary data collected from a literature study. Data used in the presentation of the Palestinian context have been collected from the literature that used non-canonical texts which cover the context of Palestine during the intertestamental era. To define the South African context, the study uses academic literature supplemented by publicly available reports and electronic news articles.

\section{RELIGIOUS CONTEXT OF JUDAISM DURING HELLENISM Political Influence on Religion}

This section focuses on the Jewish history that is not covered in the Bible. It covers the events that constitute what is termed the intertestamental period which serves as a bridge between the Old and New Testaments. ${ }^{2}$ This period falls under the Hellenistic era which promoted the adoption of and adaptation to the Greek culture. The architect of Hellenism, Alexander the Great of Macedonia started establishing a Greek Empire by taking over control of a united Greece and her army in $336 \mathrm{BC}^{3}$ and proceeded to conquer several territories and Hellenized them. Of significance to this paper is the Ptolemies' takeover of Palestine in $301 \mathrm{BC}$ due to its consequences. Some of the key actions that they implemented after this takeover include granting the Jewish territory around Jerusalem some limited authority and giving the high priest the right to exercise internal political authority almost undeterred as long as the Jews paid taxes in full. ${ }^{4}$

During the same period, the Seleucid Empire under Antiochus embarked on a campaign through which they attempted to exterminate the exclusive monotheism of Judaism. This plan included actions such as the occupation of the Jewish temple square on a Sabbath in 167 BC; forcing Jews to offer sacrifices to Zeus on a substitute altar in the Jewish temple; and forbidding Jews from observing the Sabbath, reading the Torah, circumcision, and sacrificing to their God. ${ }^{5}$ In enforcing these violations of the Jewish religious precepts, Antiochus committed atrocities such as executing mothers who had circumcised their sons. ${ }^{6}$ These violations and violence invoked a Jewish rebellion that was led by the Hasmonean family. Hasmonean militants' victories culminated in the establishment of an independent Jewish state that preserved their Jewish faith in 167 BC. ${ }^{7}$ They started this rebellion by killing a Jew who offered sacrifice to Zeus and a Syrian official who had forced him to do so. ${ }^{8}$ They proceeded to demolish Zeus's altar while simultaneously defying compulsory pagan sacrifices imposed on the Jews. ${ }^{9}$ Their defiance and surprise victories resulted in the restoration of the Jewish temple worship and Hebrew regaining the status of official language to the point of getting coins inscribed in Hebrew during the 79 years of the Hasmonean state. ${ }^{10}$ The Hasmoneans realized these achievements amidst a concomitant civil war between anti-Hellenistic and pro-Hellenistic Jews. ${ }^{11}$

The effects of colonial occupation also had an impact on the high priesthood in the land. It destabilized the priestly tradition by inducing personal gain and giving some political authority to the office of the high

\footnotetext{
Gerald O. West, "People's theology, prophetic theology, and public theology in post-liberation South Africa" in The Bible and Sociological Contours: Some African perspectives: festschrift for professor Halvor Moxnes, 71-87 (New York: Peter Lang, 2018), 72.

2 Ferdinand E. Deist, From Eden to Rome: the narrative literature of the Bible: story, composition and author's point of view (Pretoria: Van Schaik Publishers, 2004), 128.

Deist, From Eden to Rome, 128.

Deist, From Eden to Rome, 129.

Deist, From Eden to Rome, 134.

6 Isaac Boaheng, An African Background to the Old Testament (Accra: Noyam Publishers, 2021), 122.

Kenneth Atkinson, A history of the Hasmonean State: Josephus and Beyond (London: Bloomsbury Publishing, 2016$), 23-25$.

Deist, From Eden to Rome, 134.

9 Atkinson, A history of the Hasmonean State, 26.

10 Deist, From Eden to Rome, 135.

11 Jonathan E.T. Kuwornu-Adjaottor, A Background to the New Testament for College Students and Pastors (Accra: Noyam Publishers, 2020), 10.
} 
priest. These actions wittingly or inadvertently catalyzed dishonesty and bred self-interests among priestly houses, including division according to political ideology. There were those who supported Hellenism and those who had nostalgia of Egyptian rule. ${ }^{12}$ Those who were pro-Egyptian lost favor in the eyes of the Roman Empire and faced consequences. For instance, Onias III who was conservative with clear support to the Egyptian rule was deposed and later assassinated, and his son had to flee to Egypt where according to Everett Ferguson founded a temple for the military colony of Jewish settlers to further his commitment to a proEgyptian policy. ${ }^{13}$ The colonial empire rewarded his brother Jason for being pro-Hellenism by giving him the high priest position. Antiochus later replaced him with Menelaus who bribed his way to the high-priesthood, partly because Jason did not support his radical Hellenistic agenda in full. ${ }^{14}$ All these developments illustrate Antiochus's determination to destabilize the office of the high priest by transforming it into a quasi-political entity which he controlled through the appointment and removal of high priests at will ${ }^{15}$ All these were done in full contravention of the Jewish tradition of appointing high priests from the tribe of Levi. ${ }^{16}$

\section{Religion and Political Ideology}

The Roman Empire, Jewish priestly elite, and Galilean peasants had unique political ideologies which were informed by their respective religious convictions. The colonial government applied an imperialist theology which advanced that Rome was chosen by the gods to rule in perpetuity and temples provided a divine sanctuary that sustained an impression that the ruler has been ordained by the gods with a mandate from above. ${ }^{17}$ Based on this ideology, Rome had a long list of interests, such as using military force to expropriate land and do anything with it as rulers saw it fit; taxation of the fishing industry to control the sea; full control of the means of production; political propaganda; social control based on intimidation; and use of patronclient relationship and so forth. ${ }^{18}$ All these forms of interest were meant to entrench the rule of the Roman aristocrats with a deliberate purpose to amass wealth to sustain their minority rule.

Another ideology that prevailed in the area during that time was held by the Jewish priestly elite. They perceived that God fully expressed the divine order of the world during creation and they were supposedly ordained by God to exercise control over the Galilean peasants, including the right to demand tithes and offerings from them. ${ }^{19}$ The marginalized Galilean peasantry maintained that the land belonged to Yahweh and is the Promised Land given to them by him as a blessing. In line with this ideology, they showed their allegiance to Yahweh through their religious practices. These included pilgrimage festivals in celebration of Yahweh's liberation power and keeping the land as their inheritance from Yahweh which they perceived as inalienable. ${ }^{20}$

\section{Religion as a Resource to the Jews}

Religion amongst the Jews did not only serve as a resource to shape their political ideology but was also used to guide their social life, including to shape their defense mechanisms. Although intertestamental Israel could be viewed as adherents of a monolithic Judaism, it comprised a diversity of thought and practice, ${ }^{21}$ in addition to the traditional distinction between Palestinian Judaism and Hellenistic Diaspora Judaism. ${ }^{22}$ This implies that there were various approaches used in the application of Scripture to interpret their context and/ or to cope with their prevailing circumstances. This diversity is reflected in the multiple sects that co-existed during the era. In the midst of this diversity, religion continued to form the meaning system of society while

\footnotetext{
12 Deist, From Eden to Rome, 133.

13 Everett Ferguson, Backgrounds of Early Christianity (Grand Rapids: Eerdmans Publishing Company, 1989 ), 322.

14 Deist, From Eden to Rome, 133.

15 Boaheng, An African Background to the Old Testament, 120-121.

16 Boaheng, An African Background to the Old Testament, 120.

17 Ernest van Eck, "Jesus and violence: critical reading of the tenants in Mark 12:1-12 and Thomas 65," in Coping with violence in the New Testament, 101 - 131 (Leiden: Koninklijke Brill NV, 2012) 108.

18 Van Eck, Jesus and violence, 112-113.

19 Van Eck, Jesus and violence, 114.

${ }^{20}$ Van Eck, Jesus and violence, 115.

${ }^{21}$ Jim R. Sibley, "Jewish Groups in the First Century," In A Handbook on the Jewish Roots of the Christian Faith, 123-130 (Peabody: Hendrickson Publishers, 2019), 123.

${ }^{22}$ Ferguson, Backgrounds of early Christianity, 316.
} 
simultaneously feeding to the monarchy, economic and political systems through ideology. ${ }^{23}$ This diversity was explicitly reflected in the scribal tradition, social movements, priests, Pharisees and Sadducees.

The scribes gained prominence in the study and interpretation of the Law of Moses subsequent to the return from Babylonian Exile. ${ }^{24}$ As some of the Jews were illiterate, scribes played a pivotal role in scripture reading and interpretation. They were also involved in the tedious manual work of copying the scrolls for the literate. Some of the prominent scribes during the period were Ezra and Ben Sira. Although they both subscribed to Judaism, they had different approaches to the study of the Torah. Ezra promoted a lay study of the Law while promoting nationalistic-isolationist tradition which stressed the isolation of the Jews from other nations, including forbidding intermarriages with foreign nationals. ${ }^{25}$ Contrary to Ezra's nationalisticisolationist tradition, Ben Sira stood for an inclusive Judaism. ${ }^{26}$ Through this thinking, he used his writings to lay down broad guidelines for living a good life without any legalistic single-minded approach. ${ }^{27}$ This approach which was well received by some liberal aristocrats and temple leaders was partly informed by his deep exposure to Hellenism.

In order to cope with the challenges of that era, a number of social or religious movements emerged. Some of these movements included Chasidim, the Essenes, and the Qumran. They developed ideologies which sided either with the oppressed or the oppressor. For instance, members of the Chasidim were critical of the Jewish officialdom. Due to this stance, they could not be recognized in the temple worship or in the Torah although they had influential apocalyptic writings. ${ }^{28}$ The Essenes and the Qumran community were another form of Chasidim that withdrew from the temple worship in Jerusalem at the time when Jonathan became a high priest in objection to the unlawful high-priesthood of the Hasmoneans. ${ }^{29}$

Alongside the Chasidim movement were the two opposing parties of the Sadducees and Pharisees. Ferdinand Deist observes that the Pharisees emphasized the individual character of religion, the individual's relation to God, immorality, the retribution in the afterlife, and belief in angels and demons. ${ }^{30}$ While some of them did this hypocritically, Jonathan Kuwornu-Adjaottor argues that many of them were virtuous and good. ${ }^{31}$ Contrary to the ideology held by the Pharisees were the Sadducees' inverse conviction. They rejected all individualistic and eschatological ideas including all supernatural phenomena while standing by the idea of a national God, i.e. the God of Israel only. These parties also had differing views on the concept of purity. The Pharisees emphasized ethical purity while the Sadducees were concerned with ritual purity. ${ }^{32}$

\section{RELIGIOUS CONTEXT OF POST-APARTHEID SOUTH AFRICA Recognition of Religious Pluralism}

South Africa like many other countries is a country of many cultures and religions. ${ }^{33}$ This reality is reflected in the results of the community survey conducted by Statistic South Africa in 2016. These results show that of the 55.6 million South Africans, about 43.4 million of them are adherents of some Christian faith. ${ }^{34}$ With at least $78 \%$ of the population regarding themselves as Christians, it is evident that Christianity is the populous religion in the country. Scholars such as Raj Mestry note that Christianity used to receive special preference during the apartheid era to an extent that the government of the day promulgated an act in 1967 which exclusively promoted Christianity in public schools. ${ }^{35}$ This practice was abolished by the post-apartheid government through the discontinuation of religious instruction in schools in favor of religious education. The

${ }_{23}$ Malina, Bruce J, The social gospel of Jesus: The kingdom of God in Mediterranean perspective (Minneapolis: Fortress Press, 2001), 16.

24 Sibley, Jewish Groups in the First Century, 126.

25 Deist, From Eden to Rome, 141.

26 Deist, From Eden to Rome, 144.

27 Ferguson, Everett, Backgrounds of early Christianity (Grand Rapids: Eerdmans Publishing Company, 2003 ), 445.

28 Deist, From Eden to Rome, 145.

29 Deist, From Eden to Rome, 145.

30 Deist, From Eden to Rome, 147.

31 Jonathan E.T. Kuwornu-Adjaottor, A Background to the New Testament for College Students and Pastors, 63.

32 Sibley, Jewish Groups in the First Century, 124.

33 Pieter Coertzen, "Constitution, charter and religions in South Africa," African Human Rights Law Journal 14 (2014), 127.

34 Statistics South Africa, Community Survey 2016 in Brief (Pretoria: Stats SA, 2016), 42

35 Raj Mestry, "The Constitutional Right to Freedom of Religion in South African primary schools," Australia \& New Zealand Journal of Law \& Education 12, no.2 (2006), 57. 
move towards religious education could be regarded as politically correct as it emphasizes creating awareness of religious diversity while religious education was previously used to promote Christianity in the school curriculum. In this regard, confessional aspects of religion now rest with the family, home and religious community. The school curriculum is then limited to "teaching and learning about religion, religions, and religious diversity." ${ }^{36}$

The post-apartheid regime under the leadership of the African National Congress (ANC) perceives religious pluralism as a resource that should be harnessed in order to achieve "nation-building, reconstruction, and development." ${ }^{37}$ As a democratic movement, the ANC opted to pursue the route of promoting religious pluralism regardless of its noticeable Christian heritage. This heritage is acknowledged in Abraham Mzondi's work which attests that the ANC's founding president, Reverend John Dube was a Christian minister. ${ }^{38}$ Mzondi's work further sustains this revelation by briefly profiling other ANC members of the Christian faith who assumed senior public service positions in the post-apartheid era. These leaders include Reverend Frank Chikane who served as the Director-General in the Presidency and Father Simangiliso Mkhatshwa, a catholic priest who served as the inaugural mayor of the City of Tshwane. ${ }^{39}$ With these few examples of people of Christian faith in its management cadre, it is evident that the ANC has a Christian heritage which they choose not to exalt at the expense of national unity.

\section{Institutionalization of Freedom of Religion}

As a government founded on the principles of constitutional democracy, the post-apartheid government of South Africa adopted a constitution with a bill of rights which serve as a supreme law of the country and a cornerstone of democracy. ${ }^{40}$ These instruments guarantee all South Africans the right to express their religious belief or philosophical convictions in the form of teaching, practice, worship, and observances. ${ }^{41}$ Legalizing these rights in this way is an important move by the democratic government as "freedom of religion was not a constitutionally guaranteed right in South Africa" before. ${ }^{42}$ Historically, the government promoted Christianity's primacy over other religions..$^{43}$

In addition to the adoption of the constitution in 1996, the South African Charter of Religious Rights and Freedom was formulated and endorsed in $2010 .{ }^{44}$ These rights are enforced by independent institutions like the Commission for the Promotion and Protection of the Rights of Cultural, Religious and Linguistic Communities which has been established to specifically "promote and protect" all these rights of communities. ${ }^{45}$ While the establishment of this commission is commendable, some scholars note that it also unwittingly contributed to the emergence of some tendencies which threaten the beauty of religion in society. ${ }^{46}$ They argue that the protection of these rights has catalyzed the emergence of cult-like religious movements which violate human rights with their practices. For instance, some religious leaders make their members drink fuel while others occasionally spray their congregants with insecticides as part of their religious rituals under the guise of

\footnotetext{
36 David Chidester, "Religion education and the transformational state in South Africa" The International Journal of Anthropology 50, no.3 (2006), 63.

37 Chidester, Religion education, 63.

38 Abraham M.M. Mzondi, “John L.M. Dube’s Leadership: Evaluation Frank Chikane, Kenneth Meshoe and Mmusi Maimane as leaders," Conspectus 31 (2021), 84.

39 Mzondi, John L.M. Dube's Leadership, 86.

40 Raj Mestry, The Constitutional Right to Freedom of Religion in South African primary schools, 58.

41 Mestry, The Constitutional Right to Freedom of Religion in South African primary schools, 58.

42 Pieter Coertzen, "Freedom of religion in South Africa: Then and now 1652 to 2008," Verbum et Ecclesia 29, no.2 (2008), 345.

${ }^{43}$ Nicky Falkof, "Satan has come to Rietfontein: Race in South Africa's Satanic Panic,” Journal of Southern Africa Studies 38, no.4 (2012), 763.

44 Pieter Coertzen, "Constitution, charter and religions in South Africa." African Human Rights Law Journal 14 (2014), 128129.

45 Collium Banda, "Redefining religion? A critical Christian reflection on CRL Rights Commission's proposal to regulate religion in South Africa" Verbum et Ecclesia 40, no.1 (2019), 1.

46 Bekithemba Dube, Milton M. Nkoane \& Dipane Hlalele, " The ambivalence of freedom of religion, and unearthing the unlearnt lessons of religious freedom from the Jonestown incident: A decoloniality approach," Journal for the Study of Religion. 30 , no. 2 (2017), 331.
} 
Christian practices ${ }^{47}$ Perpetrators of these practices feel no remorse because they do perceive them as part of their religious expression which is supposedly protected by the constitution. In turn, these unfamiliar religious practices became the subject of the commission's investigation in $2017 .{ }^{48}$ Of note is that "the majority of the religious leaders who appeared before the commission were Charismatic or Pentecostal Christians." ${ }^{49}$

In addition to the use of legal instruments and independent institutions to promote religious pluralism, some politicians occasionally make public proclamations of these rights. For instance, addressing the Rhema Bible Church congregation on 15 March 2009 former State President Jacob Zuma acknowledged that the ANC has its roots in the Christian faith but supports all beliefs upheld by its broad membership and support base. ${ }^{50}$ By so doing, he was openly commending the role of Christianity in the country's liberation struggle while simultaneously acknowledging the religious neutrality of South Africa's constitution on issues of faith. ${ }^{51}$ With this public proclamation and prevailing instruments to institutionalize freedom of religion, adherents of some minority religious movements came forth to declare their faith publicly. For instance, Satanists successfully registered the South African Satanic Church to openly practice their faith in $2020 .^{52}$

Another notable development in line with freedom of religion in the country is the apparent use of theological reflection or the Bible without prejudice by some reigning presidents in their speeches. Gerald West notes that this propensity became prevalent after the reign of Nelson Mandela who carefully refrained from using religion and reference to a particular religion in his speeches. ${ }^{53}$ Contrary to this observation, his successor Thabo Mbeki was deliberate in the use of biblical references in public. West sustains this finding by providing a detailed analysis of Mbeki's public documents, such as a written newspaper extract from the ANC Today Article wherein he uses Matthew 4:19 to reflect on corruption, ${ }^{54}$ some of his public speeches, various policy papers and documented input to the promotion of Ubuntu. ${ }^{55}$

Thabo Mbeki's successor, Jacob Zuma expressed his familiarity with Christianity using different avenues while he was still in office. For instance, during election campaigns in 2004, he proclaimed that the ANC would rule until Jesus returns ${ }^{56}$ a statement which was widely quoted in the media in South Africa. Many people were also alarmed by his willingness to accept a symbolic pastoral position in the church. This happened when visiting independent charismatic churches in Ntuzuma, north of Durban in his home province of KwaZulu-Natal in 2007. In this event, he accepted a cleric's collar from one of the Christian leaders who declared him priest instantly. ${ }^{57}$ This move received mixed reactions from the public as he lives a lifestyle which is not appealing to some Christian denominations' biblical convictions. These mixed reactions affirm the heterogeneity of Christianity in South Africa.

\section{Infinite Diversity within Christianity}

Official statistics show that Christianity is the most populous religion in the country as it accounts for $78 \%$ of the religious population among the 55 million South Africans. ${ }^{58}$ The survey of religions in South Africa shows that Christianity has fifteen denominations. ${ }^{59}$ These denominations have diverse views and doctrines.

\footnotetext{
47 Mookgo S. Kgatle, "The unusual practices within some Neo-Pentecostal churches in South Africa: Reflections and recommendations," HTS Teologiese Studies/ Theological Studies 73, no.3 (2017), 3.

48 Banda, Redefining religion, 2.

49 Banda, Redefining religion, 4.

50 Jakub Urbaniak \& Shinyalani Khorommbi, "South Africa's Jacob Zuma and the Deployment of Christianity in the Public Sphere," The Review of Faith \& International Affairs 18, no.2 (2020), 65.

51 West, People's Theology, 78.

52 Shanice Naidoo, First Satanic Church in South Africa (Cape Town: Weekend Argus News, June 13, 2020) accessed on https://www.iol.co.za/weekend-argus/news/first-satanic-church-in-south-africa-49332892

${ }^{53}$ Gerald West, The ANC's deployment of religion in nation building: From Thabo Mbeki, to "The RDP of the Soul”, to Jacob Zuma in The Bible and Politics in Africa (Bamberg: University of Bamberg Press, 2012), 115.

54 West, The ANC's deployment of religion, 116-117.

55 West, The ANC's deployment of religion, 117-142.

${ }^{56}$ Urbaniak \& Khorommbi, South Africa's Jacob Zuma and the Deployment of Christianity in the Public Sphere, 64.

57 Chris Makhaye, Church lauds Zuma as honorary pastor, (6 May 2007). https://www.iol.co.za/news/politics/church-lauds-zuma-as-honorary-pastor-351656

58 Statistics South Africa, Community Survey 2016 in Brief, 42.

59 Statistics South Africa, Community Survey 2016 in Brief, 43.
} 
With an estimated 14 million adherents in South Africa, African Independent Churches (AICs ${ }^{60}$ are said to derive their theology from the Old Testament. ${ }^{61}$ They are also known for interpreting the Bible allegorically, literary, in a moral sense, and in an anagogic sense. ${ }^{62}$ Due to their emphasis on Old Testament traditions, they also embark on a pilgrimage to their churches' headquarters, ${ }^{63}$ predominantly during Easter and Christmas. All these characteristics are just common among the AICs in Southern Africa but do not suggest that this denomination is homogenous in any way.

Pentecostal/Evangelistic denominations come second after the AICs in terms of membership which comprises about 8 million adherents. ${ }^{64}$ For the purpose of this study, the paper will only highlight the distinguishing features and variants of Pentecostalism. Pentecostalism encompasses a wide variety of Christian practices which are "inspired by the Holy Spirit experience of the $1{ }^{\text {st }}$ Century Christians as recorded in the Acts of the Apostles. ${ }^{965}$ However, it is not a unified whole but a fragmented movement with sub-divisions ${ }^{66}$ While it continues to evolve, it could be classified under the rubric of mission or classical Pentecostalism, African Pentecostalism and neo-Pentecostalism. ${ }^{67}$ Regardless of this diversity, Pentecostalism is widely known for promoting the "restoration of the experience of the Holy Spirit in the life of the Church and the recovery of the gifts of the Spirit for Christian ministry." ${ }^{68}$ In this instance, neo-Pentecostalism tends to deviate a bit from this message by emphasizing promises of prosperity, good health, and a life free from adversity which is used by the preachers to amass wealth from congregants. ${ }^{69}$ In other words, their message usually exalts physical and material well-being over eschatology. ${ }^{70}$ They habitually use scriptures and testimonies to convince their followers to give abundantly to the local church in exchange of blessings of good health and prosperity from God.

\section{Priestly Strife in the Populous Christian Tradition}

The exposition of the religious context of intertestamental Judaism revealed that the Roman Empire fueled the feud in the office of the high priest and simultaneously exerted political control over it. This article argues that this was one of the imperial tactics to destabilize Judaism. As with populous Judaism, the study investigated the issue of priestly strife within the populous AICs. The study discovered that two of them, namely the Nazarite Baptist Church (NBC) and the International Pentecostal Holiness Church (IPHC) at some point experienced acute internal priestly strife. Unlike the Jewish priestly feud, the priestly crisis experienced by these AICs originates from an internal succession battle. Based on the study conducted by Mangaliso Matshobane and Maake Masango, some of the contributory factors to this strife include the fact that their founding pastors' mistrust of their successors, apprehension about loss of influence, and fears of financial insecurity. ${ }^{71}$ These factors contribute to the founding leaders not grooming a successor and not retiring from the priestly office until death.

In the IPHC the succession strife started in 2016 after the death of its long-serving leader Glayton Modise during the same year. His biological son and the church executive committee entered a legal battle

\footnotetext{
60 Statistics South Africa, Community Survey 2016, 43.

${ }^{61}$ Obed Kealotswe, "The nature and character of the African Independent Churches (AIC) in the $21^{\text {st }}$ Century: their theological and social agenda," Studia Historiae Ecclesiasticae 40, no.2 (2014), 232.

62 Kealotswe, The nature and character of the African Independent Churches, 233.

63 Kealotswe, The nature and character of the African Independent Churches, 237.

64 Statistics South Africa, Community Survey 2016, 43.

65 Abel Ugba, “African Pentecostals in 21st Century Ireland,” Studies: An Irish Quarterly Review 95, no.378 (2006), 164.

66 Nimi Wariboko, "Pentecostalism in Africa," Oxford Research Encyclopedia. Published online. (2017). https://doi.org/10.1093/acrefore/9780190277734.013.120

67 Mookgo S. Kgatle, \& Thabang R. Mofokeng, “Towards a Decolonial Hermeneutic of Experience in African Pentecostal Christianity: A South African Perspective.” HTS Teologiese Studies/Theological Studies 75, no.4 (2019), 3.

68 J. Kwabena Assamoah-Gyadu, "Pentecostalism and the Transformation of the Christian Landscape in Pentecostalism." in Africa: Presence and Impact of Pneumatic Christianity in Postcolonial Societies, 100-114 (Leiden: Brill, 2015$), 101$.

69 Bekithemba Dube, Milton M. Nkoane \& Dipane Hlalele, “ The ambivalence of freedom of religion, and unearthing the unlearnt lessons of religious freedom from the Jonestown incident: A decoloniality approach," Journal for the Study of Religion. 30, no.2 (2017), 337.

70 Assamoah-Gyadu, Pentecostalism and the Transformation of the Christian Landscape in Pentecostalism, 109.

71 Mangaliso M. Matshobane \& Maake Masango, "The challenge of pastoral succession in African independent Pentecostal churches," HTS Teologiese Studies/Theological Studies 76, no.2 (2020), 3-4.
} 
that culminated in a court verdict that favored the committee and named Michael Sandlana as the leader in 2019. ${ }^{72}$ Similarly, in the largest African Independent Church in the Southern Hemisphere, the Nazarite Baptist Church, ${ }^{73}$ succession battles were birthed by the death of its long-serving leader Vimbeni Shembe on 28 March 2011. The strife involved Mduduzi Shembe, the son of Vimbeni Shembe and Vela Shembe, the cousin of the deceased and was won by Vela Shembe in 2016 who later died on 24 November $2017 .^{74}$

\section{The Comparison}

Intertestamental Palestine and post-apartheid South Africa have a few factors in common regarding their respective religious contexts. They are both immersed in the domination of Abrahamic religions, i.e. Judaism and Christianity. Due to their dominance, both religions seem to have enjoyed supremacy in these respective geographies during the periods under review. The context of intertestamental Palestine was characterized by a heterogenous Judaism while post-apartheid South Africa is predominantly populated by diverse Christianity as the dominant religion.

With the advent of Hellenism, the Roman Empire used force to undermine religious pluralism while in South Africa, the democratic government uses legal instruments to promote religious pluralism. The GraecoRoman Empire applied violence and imperial politics to undermine the dominant religion of Judaism with an attempt to exterminate it. In the case of South Africa, there are no signs of any manifest intention to suppress Christianity as some of its presidents have advocated for freedom of religion while deliberately and freely applying the scriptures and biblical allegories in their political speeches or official documents. The repressive tactics used by the Roman Empire in Palestine bred violence and never culminated in the extinction of Judaism. The democratic approach used by post-apartheid South Africa contributes to a peaceful co-existence of several religions in the country unrestricted religious expressions.

The study also notes that while both religions have a huge following, in their two contexts under review, they are also evidently fragramented. As Judaism had several sects, Christianity comprises several heterogeneous denominations. With the interference of the Roman Empire in the office of the high priest, Judaism as a dominant religion during the intertestamental period witnessed priestly strife. While the government does not interfere in religious affairs of Christianity in South Africa as a dominant denomination, some AICs have experienced priestly strife due to their respective succession crises.

\section{RECOMMENDATIONS}

The findings of this study lead to the following recommendations:

- Practitioner theologians and the general public should be encouraged to read the Apocrypha for theological reflection in addition to personal edification.

- Longitudinal studies on the promotion of freedom of religion in South Africa should be considered to assess the sustainability of its current approach to protection of religious pluralism..

- Similar comparative studies on the protection of religious pluralism should be considered under various socio-political and cultural contexts across the globe.

\section{CONCLUSION}

This article has illustrated that noncanonical texts may be used for theological reflection in contemporary society by using findings of academic literature on the religious situation of intertestamental Palestine as described in the Apocrypha to assess religious pluralism in post-apartheid South Africa. The use of the Apocrypha has also enabled the study to successfully compare the religious context of intertestamental Palestine with that of postapartheid South Africa. The comparison revealed that while these societies are far apart geographically and in history, they both operate in an environment that is characterized by religious pluralism. In both societies, dominant and heterogeneous Abrahamic religions co-exist with other religions.

The study further unveiled that the political systems influence how religious pluralism is handled. In

\footnotetext{
72 Matshobane \& Masango, The challenge of pastoral succession, 2.

73 Debbie Whelan, "Unlayering the Intangible: Post-Truth in the Post Rainbow Nation," Journal of African Cultural Heritage Studies 2, no.1 (2019), 2.

74 Matshobane \& Masango, The challenge of pastoral succession, 2.
} 
democratic South Africa, it is promoted peacefully through the constitution while in intertestamental Palestine the Roman Empire attempted to crush Judaism through force and other imperial tactics. Consequently, the imperial approach in Palestine was met with counterviolence while the democratic approach culminated in the peaceful co-existence of multiple religions in South Africa, including the recognition of the Satanic Church. Therefore the author argues that the democratic approach to recognition of religious pluralism should be considered in all contexts for peaceful intercultural communication and cordial religious co-existence. Peaceful co-existence should not be perceived as promotion of unity in religious conviction or adoption of syncretism, but a way to create an enviroment for respectful evangelization.

\section{ABOUT AUTHOR}

Vusimuzi Goodman Nkuna holds an MTh from North-West University, South Africa and an MBA from the University of South Africa. He is a graduate student at the South African Theological Seminary currently at his foundational stage of his $\mathrm{PhD}$ in Theology studies. His research interests include pastoral care, the occult in Africa and interfaith dialogue.

\section{BIBLIOGRAPHY}

Asamoah-Gyadu, J. Kwabena. "Pentecostalism and the Transformation of the Christian Landscape in Pentecostalism." in Africa: Presence and Impact of Pneumatic Christianity in Postcolonial Societies, 100-114. (Leiden: Brill, 2015).

Atkinson, Kenneth A history of the Hasmonean State: Josephus and Beyond. (London: Bloomsbury Publishing, 2016).

Banda, Collium. "Redefining religion? A critical Christian Reflection on CRL Rights Commission's Proposal to Regulate Religion in South Africa." Verbum et Ecclesia 40, no.1 (2019): 1-11.

Boaheng, Isaac. An African Background to the Old Testament. (Accra: Noyam Publishers, 2021).

Chidester, David. "Religion Education and the Transformational State in South Africa." The International Journal of Anthropology 50, no.3 (2006): 61-83.

."World Religions in the World." Journal for the Study of Religion 31, no.1 (2018): 41-53.

Coertzen, Pieter. "Freedom of Religion in South Africa: Then and now 1652 to 2008." Verbum et Ecclesia 29, no.2 (2008): 345-367.

. "Constitution, Charter and Religions in South Africa." African Human Rights Law Journal 14, (2014): 126-141.

Deist, Ferdinand E. From Eden to Rome: the narrative literature of the Bible: story, composition and author's point of view. (Pretoria: Van Schaik Publishers, 2004).

Dube, Bekithemba, Nkoane, Milton M. \& Hlalele, Dipane. "The Ambivalence of Freedom of Religion, and Unearthing the Unlearnt Lessons of Religious Freedom from the Jonestown Incident: A Decoloniality Approach." Journal for the Study of Religion. 30, no.2 (2017): 330-349.

Falkof, Nicky. "Satan has come to Rietfontein': Race in South Africa's Satanic Panic." Journal of Southern Africa Studies 38, no.4 (2012): 753-767.

Ferguson, Everett. Backgrounds of early Christianity. (Grand Rapids: Eerdmans Publishing Company, 1989). . Backgrounds of early Christianity. $3^{\text {rd }}$ ed. (Grand Rapids: Eerdmans Publishing Company, 2003).

Kealotswe, Obed. "The Nature and Character of the African Independent Churches (AICs) in the $21^{\text {st }}$ century: Their Theological and Social Agenda." Studia Historiae Ecclesiasticae 40, no.2 (2014): 227-242.

Kgatle, Mookgo S. "The Unusual Practices within some Neo-Pentecostal Churches in South Africa: Reflections and Recommendations." HTS Teologiese Studies/ Theological Studies 73, no.3 (2017): 1-8.

Kgatle, Mookgo S. \& Mofokeng Thabang R. "Towards a Decolonial Hermeneutic of Experience in African Pentecostal Christianity: A South African Perspective." HTS Teologiese Studies/Theological Studies 75, no.4 (2019): 1-9.

Kuwornu-Adjaottor, Jonathan E.T. A Background to the New Testament for College Students and Pastors (Accra: Noyam Publishers, 2020). 
Makhaye, Chris. "Church Lauds Zuma as Honorary Pastor." (6 May 2007). Retrieved from https://www.iol. co.za/news/politics/church-lauds-zuma-as-honorary-pastor-351656 Accessed on 11/03/2021.

Malina, Bruce J. The social gospel of Jesus: The kingdom of God in Mediterranean perspective. (Minneapolis: Fortress Press, 2001).

Matshobane, Mangaliso M. \& Masango, Maake, “The Challenge of Pastoral Succession in African Independent Pentecostal Churches." HTS Teologiese Studies/Theological Studies 76, no.2 (2020): 1-10.

Mestry, Raj. "The Constitutional Right to Freedom of Religion in South African primary schools." Australia \& New Zealand Journal of Law \& Education 12, no.2 (2006): 57-68.

Mzondi, Abraham M.M. “John L.M. Dube's Leadership: Evaluation Frank Chikane, Kenneth Meshoe and Mmusi Maimane as Leaders." Conspectus 31 (2021): 83-96.

Naidoo, Shanice. First Satanic Church in South Africa, (Cape Town: Weekend Argus News, 06/13, 2020). Accessed online on https://www.iol.co.za/weekend-argus/news/first-satanic-church-in-southafrica-49332892 on 10/29/2021.

Sibley, Jim R. "Jewish Groups in the First Century." In A Handbook on the Jewish Roots of the Christian Faith, 123-130. (Peabody: Hendrickson Publishers, 2019).

Statistics South Africa. Community Survey 2016 in Brief. (Pretoria: Stats SA, 2016).

Ugba, Abel. “African Pentecostals in 21st Century Ireland.” Studies: An Irish Quarterly Review 95, no.378 (2006):163-193.

Urbaniak, Jakub \& Khorommbi, Shinyalani. "South Africa's Jacob Zuma and the Deployment of Christianity in the Public Sphere." The Review of Faith \& International Affairs 18, no.2 (2020): 61-75.

Van Eck, Ernest. "Jesus and Violence: Critical Reading of the Tenants in Mark 12:1-12 and Thomas 65." in Coping with Violence in the New Testament, 101 - 131 (Leiden: Koninklijke Brill NV, 2012).

Wariboko, Nimi. "Pentecostalism in Africa." Oxford Research Encyclopedia. Published online. (2017). https://doi.org/10.1093/acrefore/9780190277734.013.120.

West, Gerald. "The ANC's Deployment of Religion in Nation Building: From Thabo Mbeki, to "The RDP of the Soul", to Jacob Zuma." In The Bible and Politics in Africa, 115-144. (Bamberg: University of Bamberg Press, 2012).

.People's Theology, Prophetic Theology, and Public Theology in Post-liberation South Africa." In The Bible and Sociological Contours: Some African perspectives: festschrift for professor Halvor Moxnes, 71-87. (New York: Peter Lang, 2018).

Whelan, Debbie. "Unlayering the Intangible: Post-truth in the Post Rainbow Nation." Journal of African Cultural Heritage Studies 2, no.1 (2019): 1-16. 